\title{
The development of a system of study credits in Ukraine: the case of policy layering in the Bologna Process
}

\begin{abstract}
The Bologna Process is an intergovernmental initiative aimed to make higher education degrees compatible in Europe. Previous research into the implementation of the Bologna objectives (or action lines) views the influence of the context as a challenge. This articles suggests a different approach for analysing the implementation of the Bologna action lines. By applying the policy layering perspective, this article suggests positioning change in Bologna, and the influence of the context and its established policy conventions as two interconnected potentially productive powers that converge in one policy process. This article invites to view the context not only as a restraining problem but also as a co-moulder of Bologna implementation. To achieve this aim, the article relies on the findings from a case study of one of the Bologna action lines in Ukraine - a system of study credits in Ukraine.
\end{abstract}

Key words: the Bologna Process, Bologna, system of credits, Ukraine, policy layering

\section{Introduction}

The Bologna Process (or Bologna) began in 1999 when higher education representatives from 29 European countries gathered in the Italian city of Bologna - hence the name, the Bologna Process. The participants of the meeting signed the "Bologna declaration" (1999) in which they proclaimed their intentions to build the EHEA by converging higher education systems by 2010 . The purpose was to facilitate academic and job mobility in the region. In the "Bologna declaration" (1999), they also called upon other nearby countries to join them in the initiative. Besides the overarching goal to create the EHEA, a number of concrete objectives, called the action lines, were identified (European Higher Education Area, 2014). These objectives include the adoption of a common system of credits and cycles of study process, the development of an easily readable diploma supplement issued to graduates, the promotion of student and faculty mobility, and the assurance of higher education quality and a few others.

The implementation of the Bologna action lines has been analysed from a variety of perspectives, such as, policy lending and borrowing (Steiner-Khamsi, 2006) and policy transfer (Cusnir, 2008). Most of these discussions explain policy change in the midst of contextual contingency. Although these discussions are framed by different theoretical standpoints, they all adopt a very similar approach - recognising the influence of the context as a challenge in the way of changes in education policies.

This article aims to suggest a slightly different approach for analysing the implementation of the Bologna action lines. This approach would position change and influence 
the established policy conventions as two interconnected productive powers that converge in one policy process. This article invites researchers and policy makers to rethink the unavoidable role of the context in the implementation of the Bologna action lines. It invites readers to view the context of a particular country not only as a restraining problem for Bologna policy implementation but also as a co-moulder of Bologna implementation.

To achieve this aim, the article relies on the findings from a case study of the implementation of one of the Bologna action lines, a system of study credits, in Ukraine. This action line is a tool for organising the measurement of students' workload in credits and the accumulation and transfer of credits (European Higher Education Area, 2014). The development of this action line in Ukraine is analysed through the perspective of policy layering (Thelen, 2003). Ukraine officially joined Bologna in 2005, however it started a Bologna pilot project a year earlier. The pilot project presupposed the introduction of the credit system at a select number of universities, along with some other minor policy innovations (European Higher Education Area, 2014).

\section{Bologna and its system of study credits}

The EHEA has developed through the convergence of higher education systems with the help of a set of action lines, mentioned earlier. Since 1999, international ministerial conferences have been held every two to three years to evaluate the development of the action lines and to identify the next steps (European Higher Education Area, 2014). Although these conferences are referred to as 'ministerial,' their participants are not just the ministers of education from the Bologna countries. A number of other stakeholders, such as the European Commission, have also given their support to the project (Terry, 2010). In addition to the ministerial meetings, various workshops, conferences and meetings of international working groups, which contribute to the development of the action lines, have taken place. Since its inception, Bologna has expanded the number of objectives and clarified relevant meanings, as well as attracted new member states and new international stakeholders. Currently 48 countries, mainly the EU states and a number of its nearby countries, have volunteered to develop the EHEA (European Higher Education Area, 2014).

The ERASMUS and TEMPUS programmes have played a part in paving the way towards institutionalising the credit system as a Bologna action line. The ERASMUS Programme was established in 1987 with the aim of supporting student mobility. After almost a decade of success, this programme contributed to the formation of the basis for the EHEA (Powell \& Finger, 2013). More specifically, the credit system - the Bologna action line nowadays - was introduced in the framework of the ERASMUS Programme as a means to support student mobility through credit transfer (Weiss \& Egea-Cortines, 2008). A decade later, it was taken up to be used in the Bologna Process as one of its action lines ("Bologna declaration," 1999). A similar contribution was made by the work of the TEMPUS Programme, established in 1990 by the European Commission. The programme aimed to promote and support the modernisation of higher education in Western and Eastern Europe, Central Asia, and the Mediterranean region, through university cooperation projects and individual mobility grants (Keeling, 2006).

The credit system in Bologna today is a means for organising the measurement of student workload in credits and the accumulation and transfer of those credits (European Higher Education Area, 2014). The credit system, as well as other action lines, tends to be analysed from the following two main 
perspectives.

One perspective is focused on implementation implications. This is the most 'populated' body of literature on Bologna. It includes numerous small-scale single country studies (e.g., Portela, Sá, Alexandre, \& Cardoso, 2009; Cocosatu, 2012; Esyutina, Fearon, \& Leatherbarrow, 2013; Dakowska, 2015) and comparative studies (e.g., Dittrich, Frederiks, \& Luwel, 2004; Wodak \& Fairclough, 2010; Domilescu, 2011). Researchers look at the extent to which the action lines have been implemented in various Bologna countries. They tend to provide a brief chronology of important milestones in the national reforms as a background of the research. The main emphasis, however, is evaluating the success, or failure, of the result of implementation. The queries guiding these studies can be summarised in the following questions: "whether Bologna is a "bridge or fortress'?" (King, undated: p.1), or "whether it is a 'motor or stumbling block'?" (Teichler, 2012: p.3) for the development of higher education systems in the countries. The studies cited above reach a similar conclusion; there are more challenges associated with contextual features, rather than achievements, in national Bologna reforms.

The problems facing the implementation of the Bologna credit system are studied too. Most of these studies relate to the influence of the local context on the implementation of the credit system. For instance, Howieson and Raffe (2013) have identified institutional, epistemological and political barriers to credit transfer within the Scottish context. The implementation of the credit system in Spain faces similar challenges (Esteve-Faubel, Stephens, \& Molina Valero, 2013).

Another perspective in the literature looks at the process of the implementation of the action lines (e.g., Witte, 2006; Cusnir, 2008; Ravinet, 2008; Jakobi \& Rusconi, 2009; Dobbins and Khachatryan, 2015). This perspective compromises a much smaller body of literature, to which the empirical research in this article aims to contribute. Unlike the previous studies, which focus on the evaluative side of the implementation implications, research of the process of implementation is less concerned with the success or failure of implementation. The main focus is on what policy processes guide the implementation of reforms. All of the studies in this body of literature look at slightly different issues related to the reform process. For example, there are two extensive studies that analyse the development of higher education in Bologna in general.

One of these studies discusses the policy change under Bologna in the national context of Moldova (Cusnir, 2008). By analysing national policy documents and interviews with key higher education actors in Moldova, researchers explore the development of three Bologna action lines: the credit system, the study cycles and the diploma supplement. This study also investigates the reason Moldova joined the Bologna Process, the degree of transfer from ideas at the international scale to the national scale and the actors that participate in the policy transfer process.

Another study compares reforms in Germany, Holland, France and England (Witte, 2006). This research focuses on the ways in which the national degree structures were adapted in the Bologna context. The study looks at the actors and the development of higher education services at institutions in each country. Similarly to the Cusnir's Molodova study (2008), Witte (2006) examines 'actors and their capabilities' to map the power relations rather than to show their dynamics in Bologna. Witte (2006) sees development in the work of higher education institutions. The implementation of the Bologna action lines has been changing issues such as curricula, access to higher education, and transition to employment. The Bologna reform has been associated with a continuous policy formulation with a relative convergence across all four countries in their national institutional contexts and national 
educational discourses.

\section{The Bologna reform in the Ukrainian context}

Literature specifically about the implementation of the Bologna action lines in Ukraine is limited. This section demonstrates that the available literature echoes the foci of the wider literature on Bologna reviewed above regarding implications and process. This section also shows that the development process of the credit system needs to be further analysed. the analysis of the process of the development of the credit system needs further attention.

The body of literature focusing on the implications of the Bologna implementation in Ukraine discusses both the successes and challenges facing the programme. Some literature examines Bologna in terms of the perceived advantages that it has brought to Ukraine. First and foremost, a number of authors support the idea that it has helped improve the quality of the national higher education system (Holovaty, 2004; Nykon, 2005; Kozak, 2007). This improvement has been achieved by changing the traditional didactic education to a more student-oriented system (Suharnikov, 2012; Yatseiko, 2009), as well as opening the Ukrainian borders to increase academic mobility. Although academic mobility is still limited, Goodman (2010) argues that the reforms have made it possible. Bologna has given students an incentive to learn English, as it is necessary for study abroad programmes such as TEMPUS and ERASMUS Mundus. Furthermore, Bologna has increased the number of Ukrainian universities represented in the international rankings of higher education institutions (Pavko, 2011), and has increased the competitiveness of Ukrainian graduates abroad (Holovaty, 2004).

Further research has identified the continuation of established policies as the most significant obstacle to recent higher education reform. Because of this, Goodman (2010) argues that reform tends to be more bureaucratic than substantive. Specifically, a merely technical implementation of the new credit system has been highlighted by Luchinskaya and Ovchynnikova (2011). They argue that while the credit system was incorporated into education policies, the idea of credits as a measurement of workload was not fully explained.

In general, the success of the Bologna Process in Ukraine is hindered by the strict centralisation of higher education (Andreichuk, 2007), scarce resources, brain drain as the result of outward mobility and unwillingness to return to the Ukraine's weak socio-economic situation. A further obstacle is the substantial difference between the Ukraine's inherited Soviet model of education and the Bologna action lines (Telpukhovska, 2006; Kovtun \& Stick, 2009; Shaw, 2013). In a comparative study that includes Ukraine, centralised control is also thought to be a problem. Soltys (2015) examines Ukraine as well as the countries in the post-Soviet Central Asia and Trans-Caucasia. Soltys (2015) also concludes that, while Ukraine might be the least authoritarian among all post-Soviet countries, the implementation of Bologna in all the countries in the region suffered from a similar centralised control over higher education.

Some further studies focus on the investigation of the policy process during the Bologna reform in Ukraine. One example is by Filiatreau (2011). This author explores Ukrainian higher education policies through state documents from 2005-2009 to determine if quality assurance in the Bologna Process resulted in more transparency within higher education institutions. (The author's last name here) concludes that it has not; however, (author's last name here) claims further transparency could be achieved if the central government allowed the development of a more shared approach for managing 
higher education in the country.

Kovacs (2014) analyses Ukrainian national implementation reports, a limited number of state documents, and international ministerial communiques to trace the chronological development of the Ukrainian higher education system following each international ministerial conference. The chronological development of each Bologna action line after the "Bologna declaration" (1999) has also been researched in two further extensive studies. These studies analyse state policy documents, surveys and interviews conducted with higher education representatives.

Luhovy and Kalashnikova (2014) discuss the legal basis of the reforms while Finikov (2012) compares the achievements of the Bologna reforms in Ukraine with similar achievements in other European countries. These two studies also position the continuity of the context as an obstacle to the Bologna reform. However, they do not discuss the evolution of higher education policies before Bologna in detail.

The process of the Bologna reform seems to be viewed as the implementation of change that did not go smoothly due to past conventions. The idea that the past might shape the reforms, rather than acting as a barrier, has not been encountered in previous research of the process of the Bologna reform. This idea relies on concept of layering. Bologna action lines have not been analysed through this perspective. This article aims to conduct an analysis on layering within the credit system to suggest a new way of looking at the role of the context in the process of the Bologna reforms.

\section{Policy layering}

Thelen (2003) maintains that literature discussing path-dependence and policy change as conflicting forces is based on the punctuated equilibrium model. This model states that there are brief moments of openness of policy establishments to the acknowledgement of new ideas. Such moments are followed by an adherence to past conventions. Thelen (2003) recognises that the punctuated equilibrium model served as an important step towards the emergence of the analytical perspective, that path-dependency and change are interconnected in policy process. However, this perspective was based on the vision that path-dependency and change are two conflicting phenomena. Furthermore, Thelen (2003) states that there is a need to develop a new approach that would recognise both punctuated equilibrium and the idea that path-dependency and change are not opposing forces. This new approach would advocate the idea that they can conflate with each other in policy development.

Schickler (2001), Thelen (2003) and Boas (2007) worked to develop this approach. They argued for the need of a theory which is capable of reconciling both path-dependence and change during the process of policy implementation. For instance, Thelen (2003) analyses the the development of the British House of Lords, an institution that has demonstrated continuous strong residual power. This institution is not the same as it was at it's creation. However, it was not transformed in one instance, nor has it totally followed 'the path'.

According to Thelen (2003), layering is a process that incorporates both pathdependence and change. The notion of layering suggests a gradual incremental renegotiation of 
some elements within policy system while leaving some of elements unchanged. As such, changes accumulate on past conventions that have been left unchanged (Thelen, 2003). Layering occurs when establishments are not willing or are not capable of radical transformations (Boas, 2007).

The development of the United States Congress is discussed by Schickler (2001) as an example of layering. A radical transformation in this institution was impossible because competing groups of policy actors could not instigate radical transformations by making older structures suit their interests. The innovations were accumulated gradually by the groups based on the established conventions. The role of Congress has been changing. Its relationships with other bodies of state government have been also changing. Although Congress has kept its main policy-making responsibilities, it has also gradually been losing some of its initial power. One reason for this is because the American presidency has been developing into a more dominant force.

In conclusion, a policy process should be viewed as one that unfolds through the fluidity between path-dependence and innovations, both of which shape the other. Following the explanation of the empirical approach, this article adopts the concept of policy layering as an analytical framework for the development of the Bologna credit system in Ukraine.

\section{Research into the system of credits in Ukraine}

Arranging semi-structured interviews with higher education actors in Ukraine and searching for policy documents related to the implementation of the credit system in Ukraine were the two main methods to collect data for this study. These included a convenient sample of seven semi-structured interviews with higher education actors, and eight policy documents. Most of the data used in this study was collected in November-December, 2013. However, one document - "Law about Higher Education" (2014) - was collected a year later after that. This Law was passed after the main data collection had been finished, but it was very important for the analysis given its legislative power.

Kremen, Nikolajenko, Stepko, \& European Centre for Higher Education (UNESCO) (2006) detail that the system of higher education actors in Ukraine before and during Bologna was seen as consisting of three groups of actors: the central policy-making bodies, non-governmental organisations, and higher education institutions. An interview with one representative from the central policy-making bodies was conducted. It was a representative of the Department of Higher Education in the Ministry of Education and Science of Ukraine. Two other interviews were with representatives from a nongovernmental organisation - members of the Higher Education Reform Expert (HERE) team at the National TEMPUS office, who are also part-time academic staff members at different higher education institutions. Besides this, four more interviews were with people whose main work is academic work at higher education institutions. These four interviewees all come from one institution which is different from the institutions with which HEREs are associated. There are three higher education institutions in total, represented in this interviewee sample.

The selected policy documents include three decrees and one letter to higher education institutions, issued by the Ministry of Education and Science of Ukraine, the new Law about Higher 
Education in Ukraine, as well as three documents from 'the international level' that have been followed in Ukraine - two communiques from the international Bologna conferences and a users' guide for those who implement the credit system.

These data pertain to the time span that encompasses higher education developments in Ukraine right after its independence in August 1991 up until the issue of the new Law regarding higher education in April 2014. This data was thematically analysed, and this analysis is presented in the next section. The developments after the beginning of the Bologna pilot project in Ukraine in 2004 were looked at in more detail.

\section{The evolution of the system of credits in Ukraine through layering}

The analysis of interviews and policy documents suggests that the system of credits has been developed in Ukraine on the basis of the old national relevant policies. This analysis also suggests that these old policies had their share of shaping the system of credits in Ukraine in a particular way. It evolved from the old module system to the European credit transfer system (ECTS). The system of credits in Ukraine, at its beginning, combined the old national policy - the module system - and the new Bologna idea about credits. The resulting initiative was entitled the credit-module system. It was later further reformed into the ECTS. However, as the discussion below demonstrates, this initiative, in a nutshell, still replicates to a great degree the credit-module system. Therefore, many interviewees talk about the credit-module system in the present, assuming it is still in use and is equal to the ECTS. The old module system, the credit-module system, and the ECTS were layers, according to the policy layering approach. Each innovation or layer in a way 'needed' previous layers to 'stand' on.

\section{The old module system}

The Bologna idea about a system of credits in Ukraine was built on the basis of the module system that existed in Ukraine before Bologna. Such an idea is not directly expressed but rather implied by Finikov (2012). The author made a brief reference to a 'national module-ranking system' (p.16) as a similar old policy. Such an idea is also voiced by several interviewees:

There was something slightly resembling it [the Bologna idea of the credit system] stated in our old higher education regulation of 1993. However, this similar thing - assessment by modules - was not really used by higher education institutions (i.1, representative of the Ministry).

Indeed, the "Ministerial decree №161" (1993) was issued long before the Bologna Process. The decree states that 'a higher education institution can use modules or other forms of the evaluation of students' knowledge after a logically complete part of lectures and seminars in a certain subject, and use the results of this evaluation to calculate a final course grade.' This form of assessment after each topic of the course is presented in the decree as an alternative to the end-of-semester evaluation by exams. The idea of modules was the first layer in the development of the Bologna credit system policy. The idea of modules became a basis for the idea of the credit-module system, which started to be pushed by the Ministry since 2004.

\section{The credit-module system}

The Bologna pilot project that the Ministry initiated in 2004 placed a lot of emphasis on the development of the credit-module system. It was defined as 'a model of study process organisation 
which is based on the combination of the module way of studying and the examination units (examination credits)' ("Ministerial decree №48," 2004). The development of the credit-module system was a response from the Ministry to the call to develop $a$ credit system, as expressed in the Bologna international documents (e.g., "Prague communique," 2001).

The credit-module system in Ukraine focused on such three interrelated issues: modules, grades and credits. The module idea brought about a focus on grades accumulated with the help of modules:

It [the credit-module system] makes students and instructors work on a daily basis... Instructors have to grade students' progress several times during a semester rather than once at the end of it... Well, students used to get grades during a semester before the Bologna Process. Usually these grades were based on students' participation in a single class and not for a module. These grades were not taken into account for the calculation of the final semester course grade. These grades were in a different grading scale... There was also a module principle of grading, but it was not widely used. It is used these days (i.2, university instructor and dean).

The different grading scale the interviewee mentioned was the four-point scale. It ranged from 'two' meaning a 'fail' to 'five' meaning 'excellent.' This grading scale was substituted by the 100-point scale in the credit-module system. The new scale is the percentage-based grade range from an ' $A$ ' to an 'F' (ECTS users' guide, 2009). So the module way of studying under the credit-module system has been a preserved old national module policy. However, it was changed slightly in the Bologna context because of the idea of credits and the new grading scale. This is how the new scale has been working in practice:

Let's say there are three modules in a course. Each module has 30 points, and the final test is worth ten points. Adding everything up makes it 100 points. The process of students' knowledge assessment became more differentiated in Bologna... However, we have not quit the habit of thinking in the old scale yet and converting the grades into 100 points. If a module is worth 30 points, I give a grade in the four-point system first in my mind. Then, I compose a mathematical proportion to count how many points I can give to a student who, for example, demonstrates knowledge equal to grade 'four,' which is 'good' (i.5, university instructor).

This quote demonstrates how the established practices kept affecting new policy ideas. The Ministry turned the old modules with new grades into the foundation of the credit-module system. A new ECTS idea of measuring academic workload in credits was added to it. The credit was a new term, but although measuring academic hours spent in class has been done before, the idea of measuring academic workload as envisaged by the credit-module system was rather novel. Academic hours spent in class had been used for this purpose earlier. They disregarded the fact that students spent time for studying not only in class but outside of class as well. The credits, on the contrary, were supposed to recognise the fact that students work on tasks both inside class and outside the class, according to the ECTS. The term credit in Ukraine for a long time had been a label for the old practice of measuring workload in academic hours spent in class. It had been overlooking the idea of the complexity of tasks that students had to deal with outside of class, as well as the ideas of credit accumulation and transfer:

It was hard to transfer all study plans into these credits. One credit is 36 academic hours. We had to count all these hours to make 60 credits during one academic year and 240 credits during four years for Bachelor's Programmes, for example. It was a problem for my assistant. We spent so much time thinking hard how to do that math... My school has an agreement with... [a foreign University name omitted]. Some students from that University came to us for the whole semester and they got all 
the courses and grades transferred to their home institution. Our students could go only for one month because we do not have the courses that are at that university. So I could let them go for only one month so that they come back and catch up with what we study here, and so that they take exams at the end of the semester. There are no study plans agreements between institutions that have cooperation agreements... From the point of view of our foreign colleagues at partnership higher education institutions, certain courses have to be in the study plan, and we think that other courses have to be there (i.3, instructor and dean).

Evidently, the idea of credits was put into practice by assigning credits to the tasks that students usually did for particular programmes. This suggests that an assimilation with the ECTS idea of credits took place.

\section{The European credit transfer system}

The ECTS used to be mentioned in the Bologna international documents until 2003 as one of the variants of a credit system for the Bologna countries. In the communiques starting from 2003, the ECTS was not mentioned as one of the variants of a credit system any more. It became its only model. For instance, the "Berlin communique" (2003) claims that "Ministers stress the important role played by the ECTS in facilitating student mobility and international curriculum development' (p.4). It was also the time when the accumulation potential of credits started to be emphasised. Six years after the ECTS was agreed on the European-wide scale to be the only model, the ECTS was introduced in Ukraine (“Ministerial decree №943,” 2009).

Although some new ideas appeared in the 2009 decree, the ECTS does not seem to have brought about any significant changes to the way the credit-module system worked. The Ministerial decree itself contained limited information about how it was different from the credit-module system:

The ECTS is still absent, although the Ministry issued a decree in 2009 about the implementation of the ECTS. Nothing was said in that document about what to do with the credit-module system. People at institutions were totally confused then. They did not know what they had been implementing till 2009 if they got an order to implement something that they thought they had already implemented... Most of the educational community in Ukraine thinks today that they have implemented the ECTS if they use the credit-module system (i.6, representative of a university and the team of the HEREs).

One novel idea that appeared when the ECTS was introduced in 2009 was the change in the value of a credit. It was reduced from 36 academic hours to 30 academic hours. This suggests that the overall idea of the credit as a way of measuring workload, based on the complexity of tasks and the time students spend for completing them inside and outside the class, continued to be overlooked.

The second new idea that accompanied the introduction of the ECTS was the idea of credit accumulation. This was mentioned in the 2009 decree in addition to the idea of transfer; however, this innovation was not really taken forward. The decree did not address how the idea of credit accumulation could be accommodated with the national tradition of having a fixed course schedule at institutions. A fixed schedule of courses for study programmes did not allow for other courses to be used as substitutes, or to be recognised as part of the programme (Finikov, 2012). So the idea of the accumulation of credits, as agreed on at the international ministerial conferences, was not really addressed by the Ministry. It was perhaps because the Ministry had already introduced another related modernization initiative, which was mentioned earlier -the accumulation of points for modules during a semester to make up the final grade. 
Finally, the association of a system of credits with grades, made in the credit-module system, continued in the ECTS in Ukraine. "Ministerial letter №1/9-118" (2000) to institutions, issued before the formal introduction of the ECTS in 2009, explained that $10 \%$ of students in class could end up with 'excellent' grades which is equivalent to an 'A,' $25 \%$ with 'very good' which is equivalent to a ' $\mathrm{B}$,' $30 \%$ with 'good' which is equivalent to a ' $\mathrm{C}$, ' $25 \%$ with 'satisfactory' which is equivalent to a ' $\mathrm{D}$,' and $10 \%$ with 'not satisfactory' which is equivalent to an 'F.' Here is a comment from an interviewee about this:

....the international ECTS suggests that a certain proportion of students get certain grades. Let's say, only $10 \%$ get 'A' grades, and $25 \%$ get ' $B+$,' but it is just an example, it is statistics. What happens in Ukraine at some institutions? Instructors come at the beginning of a semester and say to a group of 20 students that, 'according to the Bologna Process, only two of you can get an 'A, 'seven can get a ' $B$ ', and so on. Such occasions are not rare (i.7, representative of a university and the team of the HEREs).

Indeed, the idea of percentages of students with different grades in class stems from the international ECTS Users' Guide (2009). It suggests that the distribution of students with different grades in class might vary. A reason for the interpretation of this idea as some sort of a rule may be related to state funding of students. One interviewee mentioned off the record that there has been a limit on the number of raised stipends for state funded students. Students who get excellent marks for most courses receive raised monthly stipends for the next semester, while those who do not perform that well get lower stipends. A similar problem before Bologna had been solved by purposefully downgrading some students in order to have fewer students for stipends in the end (i.4, instructor and dean's assistant). Ensuring that the number of students with excellent marks does not outbalance the number of available raised stipends may be done through the appropriation of the ECTS idea. This, in turn, further illustrates how the development of the innovative policy ideas is guided and problematised by the practices established before Bologna, and how the established practices are reshaped by the modernisation agenda.

The latest development in terms of the ECTS has been outlined in the new "Law about Higher Education" (2014). It has defined the ECTS as 'a system of transfer and accumulation of credits, which is used in the European Higher Education Area (EHEA) with the aim to provide, recognise and confirm qualifications and education components and support academic mobility of students.' The Law further explains that the ECTS 'is based on defining students' workload, which is required for achieving target results of studies, and which is calculated in the credits of the ECTS' (chapter 1, article 1). The Law has specified the ECTS, yet the explanation of how to measure workload and how to enact transfer is limited. Another problem is the absence of the guidelines on whether the module way of grading students should be preserved. All of these issues might make the ECTS continue the practices established earlier in the credit-module system. This could make the ECTS a continuation of the credit-module system in a slightly more specified form.

\section{Conclusion}

The credit system in Ukraine has been developed by the higher education actors in Ukraine through a number of steps - layers. These were the module system, the credit-module system, and the ECTS.

The module system became the first layer in the development of the Bologna credit system policy in Ukraine. The usage of the old national policy in the development of the credit system can be 
only partially seen as a constraining influence of the Ukrainian context in the implementation of the Bologna action line because this Bologna action line, as defined at the international level, was quite vague. At the beginning of Bologna, the ECTS was suggested only as one of the options for a credit system. It became presented as the Bologna credit system later. Thus, the module system in Ukraine became a useful ground for the development and specification of a limited and vague meaning of a Bologna credit system particularly in the Ukrainian context.

Only some aspects of the influence of the context on the implementation of the Bologna action line in Ukraine can be seen as restraining. For instance, the idea of credits, originally meant for measuring academic workload of students inside and outside of class has been a new label for the old Ukrainian practice of measuring the workload inside the class. Moreover, this put the credit transfer idea, which should have been key in the credit system policy, in a secondary position. Despite this, the discussion of the development of the credit system policy in Ukraine in general has demonstrated how productive the influence of the past policies can be in shaping, specifying and further developing the meaning of Bologna ideas.

This article has suggested that there is a need to rethink the unavoidable role of the context in the implementation of the Bologna action lines. It has demonstrated that the context can be a co-moulder of Bologna implementation, and not just a restraining problem. Further research into Bologna from a policy layering perspective can shed more light on the exact ways in which the context shapes policy development in relation to each of the Bologna action lines in different Bologna countries.

\section{References}

Andreichuk, S. K. (2007). Derzhavne upravlinnya reformuvannya vyshchoyi osvoty v Ukrayini $v$ koneksti Bolonskogo Protsesu [State management of higher education reform in Ukraine in the context of the Bologna Process] (Candidate of Sciences). Lviv Regional Institute of State Management, Lviv, Ukraine. Retrieved August 9, 2015, from http://irbis-nbuv.gov.ua/cgibin/irbis64r_81/cgiirbis_64.exe?Z21ID=\&I21DBN=ARD\&P21DBN=ARD\&S21STN=1\&S21REF=1 $0 \& S 21 \mathrm{FMT}=$ fullwebr $\& \mathrm{C} 21 \mathrm{COM}=\mathrm{S} \& \mathrm{~S} 21 \mathrm{CNR}=20 \& \mathrm{~S} 21 \mathrm{P} 01=0 \& \mathrm{~S} 21 \mathrm{P} 02=0 \& \mathrm{~S} 21 \mathrm{P} 03=\mathrm{A}=\& \mathrm{~S} 21 \mathrm{COL}$ ORTERMS $=1 \& \mathrm{~S} 21 \mathrm{STR}=\% \mathrm{D} 0 \% 90 \% \mathrm{D} 0 \% \mathrm{BD} \% \mathrm{D} 0 \% \mathrm{~B} 4 \% \mathrm{D} 1 \% 80 \% \mathrm{D} 0 \% \mathrm{~B} 5 \% \mathrm{D} 0 \% \mathrm{~B} 9 \% \mathrm{D} 1 \% 87 \% \mathrm{D} 1$ $\% 83 \%$ D0\%BA\%20\%D0\%A1.\%D0\%9A.\$

Berlin communique. (2003, September 19). Retrieved August 9, 2015, from http://www.ehea.info/Uploads/Declarations/Berlin_Communique1.pdf

Boas, T. C. (2007). Conceptualising continuity and change: the composite-standard model of path dependence. Journal of Theoretical Politics, 19(1), 33-54.

Bologna declaration. (1999, June 19). Retrieved August 9, 2015, from http://www.magnacharta.org/resources/files/BOLOGNA_DECLARATION.pdf

Cocosatu, M. (2012). Diploma supplement - instrument of the quality assurance process in the Romanian higher education? Presented at the European Integration - Realities and Perspectives, National School of Political Studies and Public Administration (NSPSPA) - Faculty of Public Administration, Romania. Retrieved August 9, 2015, from file://C:/Users/Ira/Downloads/SSRNid2156879.pdf 
Cusnir, S. (2008). Transferring Bologna ideas into national higher education policy practices: the case of the republic of Moldova (MSc). University of Oslo, University of Tampere, University of Aveiro, Norway, Finland, Portugal. Retrieved August 9, 2015, from http://www.erisee.org/downloads/library_moldova/Transffering\%20Bologna\%20Ideas\%20into\%20Na tional\%20Higher\%20Education\%20Policy\%20Moldova\%20Republic.pdf

Dakowska, D. (2015). Between competition imperative and Europeanisation: the case of higher education reform in Poland. Higher Education, 69(1), 129-141.

Dittrich, K., Frederiks, M., \& Luwel, M. (2004). The implementation of 'Bologna' in Flanders and the Netherlands. European Journal of Education, 39(3), 299-316.

Dobbins, M., \& Khachatryan, S. (2015). Europeanisation in the 'Wild East'? Analysing higher education governance reform in Georgia and Armenia. Higher Education, 69(2), 189-207.

Domilescu, G. (2011). Student centred learning, major objective in the higher educational teaching-learning process. Journal of Educational Sciences / Revista de Stiintele Educatiei, 13(2), 135 .

ECTS Users' Guide from the European Commission, \& Directorate-General for Education and Culture (Eds.). (2009). ECTS users' guide. Luxembourg: EUR-OP. Retrieved August 9, 2015, from http://ec.europa.eu/education/tools/docs/ects-guide_en.pdf

Esteve-Faubel, J., Stephens, J., \& Molina Valero, M. (2013). A quantitative assessment of students' experiences of studying music: a Spanish perspective on the European credit transfer system (ECTS). British Journal of Music Education, 30(01), 59-84.

Esyutina, M., Fearon, C., \& Leatherbarrow, N. (2013). The Bologna process in higher education: an exploratory case study in a Russian context. Quality Assurance in Education, 21(2), $145-161$.

European Higher Education Area. (2014). Retrieved August 9, 2015, from http://www.ehea.info/

Filiatreau, S. (2011). Ukraine's participation in the Bologna Process: has it resulted in more transparency in Ukrainian higher education institutions? International Research \& Review: Journal of the Phi Beta Delta H, 1(1), 1-47.

Finikov, T. (Ed.). (2012). Vhodzhennya natsionalnoyi systemy vyshchoyi osvity $v$ Yevropeiskyi prostir vyshchoyi isvity ta naukovoho doslidzhennya [The integration of the national system of higher education into the European space of higher education and research]. Kyiv: Takson. Retrieved August 9, 2015, from http://kno.rada.gov.ua/komosviti/doccatalog/document?id=54018

Goodman, B. A. (2010). Ukraine and the Bologna Process: convergence, pluralism, or both? Presented at the 12th Berlin Roundtables on Transnationality, Berlin, Germany. Retrieved August 9, 2015, from http://downloadconfirm.net/file/0415J7

Holovaty, M. (2004). Osvita Ukrayiny: zupynytysya i ohlyanutysya [Education of Ukraine: stop and look back]. In Bolonskyi protses: perspektyvy i rozvytok $u$ konteksti intehratsiyi Ukrayiny $v$ Yevropeiskyi prostir vyshchoyi osvitu [The Bologna Process: opportunities and development in the context of Ukraine's integration into the European higher education space (p. 197). Kyiv: MAUP. 
Howieson, C., \& Raffe, D. (2013). The paradox of Scotland: limited credit transfer in a creditbased lifelong learning system. Oxford Review of Education, 39(3), 366-384.

Jakobi, A. P., \& Rusconi, A. (2009). Lifelong learning in the Bologna Process: European developments in higher education. Compare: A Journal of Comparative and International Education, $39(1), 51-65$.

Keeling, R. (2006). The Bologna Process and the Lisbon research Agenda: the European Commission's expanding role in higher education discourse. European Journal of Education, 41(2), 203-223.

King, C. (undated). The Bologna Process: bridge or fortress? A review of the debate from a North American perspective. Presented at the Canada-EU Bridge Project, Institute of European Studies, Institute of British Columbia. Retrieved August 9, 2015, from http://www.cceae.umontreal.ca/IMG/pdf/Conrad_King_Literature_Review.pdf

Kovacs, K. (2014). The Bologna Process in Ukraine. In T. Kozma, M. Rébay, A. Óhidy, \& É. Szolár (Eds.), The Bologna Process in Central and Eastern Europe (1. Aufl). Wiesbaden: Springer Fachmedien Wiesbaden $\mathrm{GmbH}$.

Kovtun, O., \& Stick, S. (2009). Ukraine and the Bologna Process: a case study of the impact of the Bologna Process on Ukrainian state institutions. Higher Education in Europe, 34(1), 91-103.

Kozak, T. S. (2007). Organizatsiino-pedagogochni zasady vprovadzhennya kredytnomodulnoyi systemy pidgotovky fahivtsiv u vyshchyh pedagogichnyh zakladah III-IV rivniv akredytatsiyi [Organizational-pedagogical foundations of the implementation of the credit-module system in the preparation of specialists at higher education establishments of III-IV levels of accreditation] (Candidate of Sciences). Vinnyatsya State Pedagogical University named after M. Kotsyubynsky, Vinnyatsya. Retrieved August 9, 2015, from http://irbis-nbuv.gov.ua/cgibin/irbis64r_81/cgiirbis_64.exe

Kremen, V., Nikolajenko, S., Stepko, M., \& European Centre for Higher Education (UNESCO). (2006). Higher education in Ukraine. Bucharest: UNESCO-CEPES.

Law about higher education. (2014). Retrieved August 9, 2015, from http://zakon4.rada.gov.ua/laws/show/1556-18

Luchinskaya, D., \& Ovchynnikova, O. (2011). The Bologna Process policy implementation in Russia and Ukraine: similarities and differences. European Educational Research Journal, 10(1), 21.

Luhovy, V., \& Kalashnikova (Eds.). (2014). Pravovi zasadu realizaciyi Bologskogo Protsesu $v$ Ukrayini [Legal basis of the implementation of the Bologna Process in Ukraine]. Kyiv: DP NVTS Prioritety. Retrieved August 9, 2015, from http://www.irf.ua/knowledgebase/publications/pravovi_zasadi_realizatsii_bolonskogo_protsesu_v_ukr aini/

Ministerial decree №161 "About the confirmation of the regulation concerning the study process organisation at higher education establishments." (1993, June 2). Retrieved August 9, 2015, from http://zakon4.rada.gov.ua/laws/show/z0173-93

Ministerial decree №48 “About a pedagogical experiment on credit-module system of organisation of the study process." (2004, January 23). Retrieved August 9, 2015, from https://www.google.com.ua/url?sa=t\&rct=j\&q=\&esrc=s\&source=web\&cd=1\&cad=rja\&uact=8\&ved= 
0CBwQFjAAahUKEwj_mt_asZzHAhVGVSwKHVGhDWY\&url=http\%3A\%2F\%2Fold.mon.gov.ua $\% 2$ Fimages\%2Ffiles\%2Fosvita\%2FEvrointehraciya\%2Fmon_48.doc\&ei=cXvHVbeG8aqsQHRwrawBg\&usg=AFQjCNF4jX4JOyHhKQITZWAV7KuMWY14kA\&sig2=HQXI36SqDiV MGZY2_h48Hw\&bvm=bv.99804247,d.bGg

Ministerial decree №943 "About the implementation of the European credit-transfer system at higher educational establishments of Ukraine." (2009, October 16). Retrieved August 9, 2015, from http://www.abiturient.in.ua/ua/bologna_process_ua/nakaz_943_ua

Ministerial letter №1/9-118 "Recommendations concerning filling in the higher education diploma supplement." (2000, April 28). Retrieved August 9, 2015, from http://www.officemetodist.com.ua/data/13637/

Nykon, O. K. (2005). Do pytannya pidhotovky muzykanta za vymogamy Bolonskogo protsesu [Concerning the problem of the preparation of a musician according to the requirements of the Bologna Process]. Almanac of Zhytomyr State University named after I. Franko, 21, 103-105.

Pavko, A. (2011). Suchasni nauky v konteksti Yevropeiskoyi modernizatsiyi vyshchoyi osvity $\mathrm{v}$ Ukrayini [Contemporary sciences in the context of European modernisation of higher education in Ukraine]. Visnyk, 9, 25-30.

Portela, M., Sá, C., Alexandre, F., \& Cardoso, A. (2009). Perceptions of the Bologna Process: what do students' choices reveal? Higher Education, 58(4), 465-474.

Powell, J. J. W., \& Finger, C. (2013). The Bologna Process's model of mobility in Europe: the relationship of its spatial and social dimensions. European Educational Research Journal, 12(2), 270.

Prague communique. (2001, May 19). Retrieved August 9, 2015, from http://www.ond.vlaanderen.be/hogeronderwijs/bologna/documents/mdc/prague_communique.pdf

Ravinet, P. (2008). From voluntary participation to monitored coordination: why European countries feel increasingly bound by their commitment to the Bologna Process. European Journal of Education, 43(3), 353-367.

Schickler, E. (2001). Disjointed pluralism: institutional innovation and the development of the U.S. Congress. Princeton: Princeton University Press.

Shaw, M. A. (2013). Flawed implementation or inconsistent logics? Lessons from higher education reform in Ukraine. European Education, 45(1), 7-24.

Soltys, D. (2015). Similarities, divergence, and incapacity in the Bologna Process reform implementation by the former socialist countries: the self-defeat of state regulations. Comparative Education, 51(2), 179-195.

Steiner - Khamsi, G. (2006). The economics of policy borrowing and lending: a study of late adopters. Oxford Review of Education, 32(5), 665-678.

Suharnikov, Y. (2012). Kontseptualni pidstavy rozrobky i vprovadzhennya natsionalnoyi ramky (akademichnyh) kvalifikatsii Ukrayiny [Conceptual bases of the creation and implementation of national qualification framework in Ukraine]. Vyshcha Shkola, 3, 16-38.

Teichler, U. (2012). International student mobility and the Bologna Process. Research in Comparative and International Education, 7(1), 34. 
Telpukhovska, V. (2006). Bologna Process in the national context of Ukraine - tribute or fashion or necessary step (Master's). University of Tampere, Finland. Retrieved August 9, 2015, from https://tampub.uta.fi/bitstream/handle/10024/94036/gradu01456.pdf?sequence=1

Terry, L. (2010). The Bologna Process and its impact in Europe: it's so much more than degree changes. Vanderbilt Journal of Transnational Law, 41(107), 107-228.

Thelen, K. (2003). How institutions evolve: insights from comparative historical analysis. In J. Mahoney \& D. Rueschemeyer (Eds.), Comparative historical analysis in the social sciences.

Cambridge, U.K.; New York: Cambridge University Press.

Weiss, J., \& Egea-Cortines, M. (2008). Teaching applied genetics and molecular biology to agriculture engineers. Application of the European Credit Transfer System. European Journal of Engineering Education, 33(1), 59-66.

Witte, J. K. (2006). Change of degrees and degrees of change: comparing adaptations of European higher education systems in the context of the Bologna process. CHEPS, Centre for Higher Education Policy Studies, Enschede. Retrieved August 9, 2015, from http://www.che.de/downloads/C6JW144_final.pdf

Wodak, R., \& Fairclough, N. (2010). Recontextualising European higher education policies: the cases of Austria and Romania. Critical Discourse Studies, 7(1), 19-40.

Yatseiko, M. H. (2009). Demokratyzatsiya yak zakonomirnist modernizatsiyi osvity v konteksti globalozatsiyi [Democratisation as a rule of modernisation of education in the context of globalisation] (Candidate of Sciences). National Pedagogical University named after M. Drahomanov, Kyiv. Retrieved August 9, 2015, from http://www.irbis-nbuv.gov.ua/cgibin/irbis_nbuv/cgiirbis_64.exe 